\title{
ヒト卵巣組織由来の培養株化細蚫の産生する Plasminogen activator
}

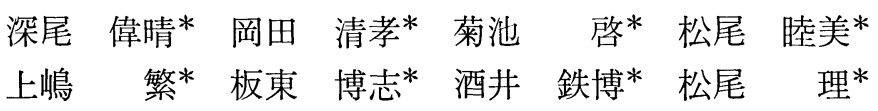

Studies on plasminogen activator produced by the cultured cell line from the tissue of human ovary

\author{
Hideharu FUKAO* Kiyotaka OKADA*, Hiraku KIKUCHI*, \\ Chikami MATSUO*, Shigeru UESHIMA*, Hiroshi BANDO*, \\ Tetsuhiro SAKAI* and Osamu MATSUO*
}

Key words: cultured cells, plasminogen activator, UK, t-PA, fibrin affinity

A novel cell line named B-1085 with morphological and physiological stability was established from the tissue cultured cells of the human ovary, which produced high level of plasminogen activator (PA) into the cultured medium.

B-1085 was subcultured under the following conditions: MEM medium containing $10 \% \mathrm{FCS}, 2 \mathrm{mM}$ glutamine and $300 \mathrm{ppm}$ penicillin with $5 \times$ $10^{5}$ cells $/ 10 \mathrm{ml}$ of medium $/ 25 \mathrm{~cm}^{2}$-flask, incubated at $37^{\circ} \mathrm{C}, 5 \% \mathrm{CO}_{2}$ for 7-10 days. This cell line could be cultured on microbeads with a good adhesion and growth secreting high concentration of PA into the medium.

PA produced by B-1085 was investigated on its enzymatic identification. This PA was successfully purified using high performance liquid chromatography with zinc chelate-5PW column resulting in a single band ( $55 \mathrm{~K}$ ) on SDS-polyacrylamide gel electrophoresis. Enzymography revealed that $55 \mathrm{~K}$ protein band had a fibrinolytic activity and no other active band was detected. Immunological study showed that the PA cross-reacted with anti-UK antibody but not with anti-t-PA one. These results suggest that the PA was similar to UK in the the point of molecular weight and im-

* 近畿大学医学部第二生理学 [干589 大阪府南河内郡狭山町西山], Department of Physiology, Kinki University School of Medicine, Osaka, Japan. 
munological property. On the other hand, this PA demonstrated high affinity to fibrin, indicating t-PA type characteristic.

\section{は じめに}

生体内の各組織では種々の plasminogen activator (以下 PA) が産生されている ${ }^{1)}$. 今回, ヒ 卜組織内 PA を検索した結果, 卵巣組織細胞の 初代培養から得られた培養株化細胞 B-1085 が その培養液中に高濃度の PA を産生することを 見出した．以下，本培養株化細胞 (以下 B-1085) の細胞学的特性, PA 産生に関する培養条件, 並びに PA の酵素学的性質について報告する.

\section{I. 材料および方法}

外科手術により得られたヒト卵巣組織を trypsin $0.05 \%$, collagenase $200 \mathrm{U} / \mathrm{m} l$ を用いた常 法に従って酵素消化による細胞分散を行い，初 代培養2をを実施した。その後，継代培養を繰り 返し, 単一の細胞群を得, 以後培養株化細胞 B-1085 として確立し実験に供した．培地は， 合成 penicillin $300 \mathrm{ppm}$, glutamine $2 \mathrm{mM}$, 未o よび牛胎児血清（GIBCO 社） $10 \%$ を含む $\mathrm{Ea}$ gle MEM 培地 (ニッスイ) を用い $5 \times 10^{5} \mathrm{cells}$ / $10 \mathrm{ml} / 25 \mathrm{~cm}^{2}$-flask (CORNING 社) の播種量 で, $37^{\circ} \mathrm{C}, 5 \% \mathrm{CO}_{2}$ 分圧下, 7-10日間培養し,

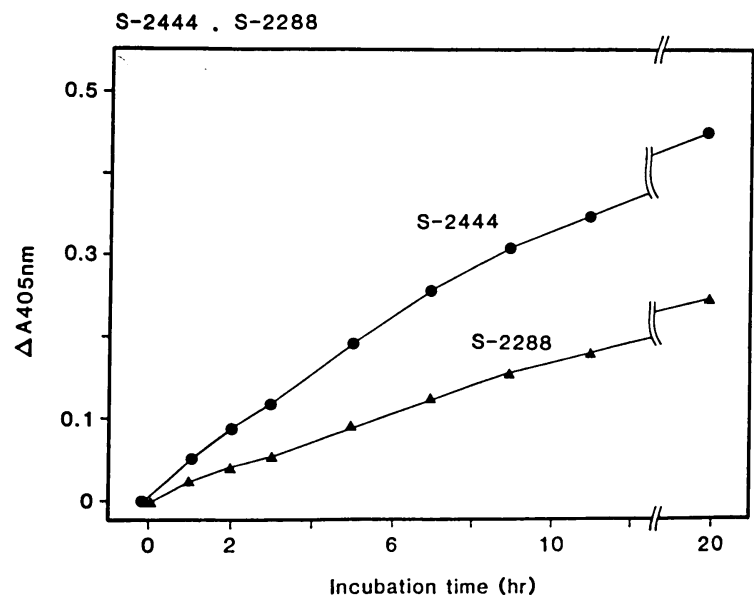

Fig. 2 S-2444 (-) or S-2288 ( amidolytic activity of PA obtained from the cultured medium of B-1085.

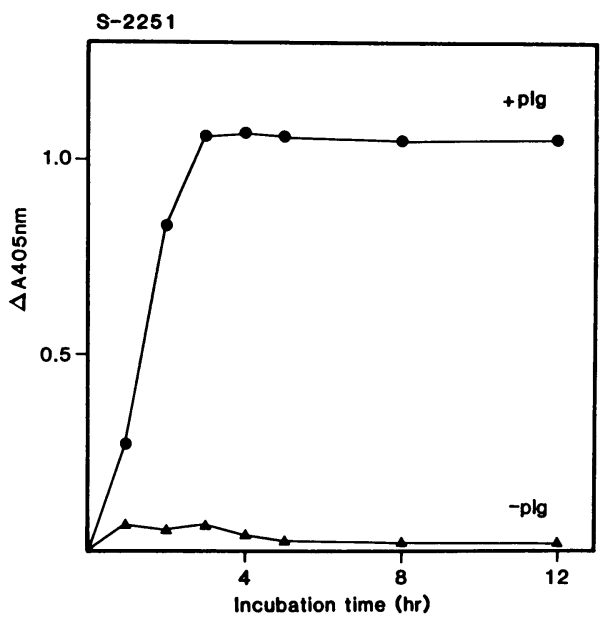

Fig. 1 S-2251 amidolytic activity of the cultured medium of B-1085 in the presence (-) or absence $(\boldsymbol{\Delta}-\boldsymbol{\Delta})$ of plasminogen.

継代を行った，Beads 培養3) には，Cytodex-1 (Pharmacia 社)を用い, $1 \times 10^{7}$ cells $/ 200 \mathrm{mg}$ beads (D.W.) $/ 80 \mathrm{~m} l$ の規模で実施した. 細胞 内外の PA 活性值は, fibrin plate 法4)，または 合成基質分解法 ${ }^{5)}$ に上り求め, urokinase (以下 UK) 換算した. 本 PA を enzymography') に より，分子量と酵素活性を明らかにした。 また, ConA-Sepharose 抢よび fibrin-Sepharose $^{7) 8)}$ を用いておの扔の, ConA およ び fibrin に対する親和性を検討し，既知の $\mathrm{UK}^{9)}$ 抢よび組織性 $\mathrm{PA}^{10)}$ (以下 $\mathrm{t}-\mathrm{PA}$ ) と 比較した. 本 PA は $\mathrm{Zn}$ chelate-5 $\mathrm{PW}$ を装 着した高速液体クロマトグラフィー11)を用 いて精製した。

\section{II. 結 果}

B-1085 は一定の条件下で既に 5 年以上 継代培養され, 培地中にPA を産生してお り（図 1)，その高生産性は安定している $\left\lceil 10 \mathrm{ml} / 75 \mathrm{~cm}^{2}\right.$-flask の無血清培養で 20$30 \mathrm{IU} / \mathrm{m} l$, melanoma(Bowes) の 2 倍以上]. 
B-1085 は microbeads によく接着し，かつ良 好な増殖を示し, beads 培養が可能であり, 培 養上清には PA 産生が認められた. Enzymography により分析すると, 本 PA は分子量約 55000 に単一の酵素活性を有しており，UK の 分子量と類似していた. しかし， UK の場合に 見られる低分子 (分子量約 33000) の活性 band は認められなかった. 合成基質に対しては S2288 より S-2444をより多く分解した（図 2 ）. 免疫学的検討では, 抗 UK 抗体により活性は 抑制された。 また fibrin に対する高い親和性が 認められた。

\section{III. 考察}

B-1085 は長期にわたり形態学的にも生理学 的にも安定して和り, 永代培養可能な樹立細胞 であると思われた，本細胞が分泌する PA は fibrin 親和性を有する点, t-PA 型であるが, 分子量, 合成基質に対する特異性及び免疫学的 性質の点からはUK 型であると思われた。

\section{文献}

1) Astrup, T.: Tissue activators of plasminogen. Fed. Proc., 25; 42 51, 1966.

2) Vahouny, G.V., Wei, R., Starkweather, R. and Davis, C.: Preparation of beating heart celis from adult rats. Science, $167 ; 1616,1970$.

3) Levine, D.W., Wong, J.S., Wang, D.I.C., et al.: Microcarrier cell culture, new methods for research-scale application. Somatic Cell Res., 3; 149 155, 1977.

4 ) Matsuo, O., Mihara, H. and Rokushima, Y.: Assessment of the thrombolytic effect of low urokinase concentrations.
Acta. Haematol. Jap., 39 (3) ; 298 305, 1976.

5) Matsuo, O., Nishida, Y., Akazawa, K. and Mihara, H.: Effect of urokinase on fiblinolysis and fiblinogenolysis. Jap. J. Physiol., 32 (6) ; 879 883, 1982.

6) Matsuo, O., Sakai, T., Bando, H., Okada, K., Nakajima, S., Takagi, O. and Izaki, S.: Plasminogen activator in bronchoalveolar fluid. Hemostasis, 16; 43 50, 1986.

7) Blombäck, B. and Blombäck, M.: Purification of human and bovin fibrinogen. Arkiv. Kemi., 10; 415 443, 1956.

8) Heene, D.L. and Matthias, F.R.: Adsorption of fibrinogen derivatives on insolubilized fibrinogen and fibrinmonomer. Thromb. Res., 2; 137 154, 1973.

9) Holmberg, L., Bladh, B. and Astedt, B.: Purification of urokinase by affinity chromatography. Biochim. Biophys. Acta., 445; 215 222, 1976.

10) Matsuo, O., Rijken, D.C. and Collen, D.: On the thrombolytic properties of human tissue plasminogen activator and urokinase. In: Urokinase: Basic and Clinical Aspects. Mannucci, P.M. and D'Angelo, A. (Ed.) London-Academic Press., pp. 55-61, 1982.

11) Matsuo, O., Tanbara, Y., Okada, K., Fukao, H., Bando, H. and Sakai, T.: Highperformance chromatographic method for the purification of tissue-type plasminogen activator. J. Chromatogr. 369; 391 397, 1986. 